\title{
How to Do Things with Organs: Moving Parts in The Duchess of Malfi
}

\begin{abstract}
This article analyzes the agency of mobile organs and parts in John Webster's The Duchess of Malfi. While criticism on the individuated part in the play has primarily focused on Ferdinand's blazonic renderings of the Duchess's body, I argue that the Duchess reappropriates her brother's language and develops what I refer to as a rhetoric of intercorporeal exchange. For the Duchess, the exchange of unruly parts organs and spirits that leave one body to enter another - has desirable rather than disastrous effects, allowing her to merge metaphysically with Antonio. In its allusions to Neoplatonism and theories of hidden sympathies, the play, I argue, dramatizes a conception of humoral subjectivity that was inextricably linked to the exchange of itinerant and invasive parts.
\end{abstract}

Warning the Duchess against the lure of remarriage, Ferdinand and the Cardinal attempt to frighten her with grotesque imaginings of her anatomy:

FERDINAND You are a widow:

You know already what man is, and therefore

Let not youth, high promotion, eloquence -

CARDINAL No, nor any thing without the addition, honour,

Sway your high blood.

FERDINAND Marry? They are most luxurious

Will wed twice.

CARDinal O fie!

FERDINAND Their livers are more spotted

Than Laban's sheep.

In their concern with what may lead to or reveal their sister's aberrant desires, the brothers describe transformations - the Duchess's mobile blood and spotted

Roya Biggie (rjbiggie@knox.edu) is an assistant professor of English at Knox College in Galesburg, IL. 
liver - within the body's interior. The Cardinal fears the 'sway', the movement and influence of the Duchess's blood, while Ferdinand attempts to frighten his sister with the image of a diseased and sickly organ. Instead of directly interrogating the Duchess's wish to re-wed, Ferdinand focuses on her liver, the organ that, according to Helkiah Crooke's Mikrokosmographia, contains 'the faculty of lust and desire.' ${ }^{2}$ Just as her blood may tarnish her reputation (at least in her brothers' eyes), the Duchess's liver may similarly move her feelings of desire and compel her to remarry. Picturing her potentially unstable blood and spotted liver, the Cardinal and Ferdinand betray an anxiety regarding the possible unruliness of their sister's anatomy. In this relatively short exchange and, as I will argue throughout this essay, Webster introduces us to a world in which the body's organs and fluids do things. $^{3}$

Scholars have demonstrated that blazonic images and dramatic representations of bodily parts abound in Webster's play. In her discussion of the Duchess's two bodies (her 'body politic' and 'body natural'), Theodora Jankowski argues that Ferdinand's references to specific parts allow him to exert control over his sister's body by 'symbolically dismembering it." ${ }^{4}$ While Linda Woodbridge acknowledges Ferdinand's attempts to regulate the Duchess's sex life, she claims that Ferdinand's obsession with his sister's body is not driven by incestuous desire but a disgust with sexuality more broadly. Woodbridge points out that Ferdinand 'fetishizes body parts, but instead of emblazoning them in sonnets, he tends to cut them off bodies and carry them around - a dead man's hand, the leg of a man'.5 Following Jankowski, Sara Morrison argues that the Duchess recognizes that Ferdinand's various forms of psychological torture - many of which rely on images of bodily fragmentation - have the potential to transform both her sense of self and her physicality; as Morrison aptly puts it, the Duchess understands 'interior states can be worn on the body'. ${ }^{6}$ According to Morrison, the Duchess resists such torment by embracing a sense of physical and mental integrity. Scholarship on the play's blazonic imagery has been crucial to exposing the precise means by which Ferdinand attempts to control and terrorize his sister as well as the Duchess's remarkable resistance to rhetorics — both imagined and literalized — intended to sexualize, confine, and dehumanize women's bodies. Yet, limited in its scope, this criticism has primarily centred on Ferdinand's rather than the Duchess's attention to the individuated part.

While critics have suggested that the Duchess remains immune to her brothers' blazonic rhetoric, the Duchess, perhaps even more radically, relies on images of corporeal fragmentation as she courts Antonio, and envisions physical transformations that have desirable rather than disastrous effects. Much like her brothers 
in the play's first scene, the Duchess recognizes the agency of organs and fluids, their ability to 'sway', transform, and thus alter the body's physical and affective states. ${ }^{7}$ Her insistence that Antonio use her ring to heal his 'bloodshot' eye initiates an exchange of spirits (vaporous fluids that coursed through the body) and then leads to a conversation littered by blazons (1.1.396). For the Duchess and Antonio too, bodily parts do things; however, the Duchess departs from Ferdinand and the Cardinal's rhetoric by describing not simply transformations within the body's interior, but organs and spirits that leave one body to enter another. Turning to the blazon, the Duchess and eventually Antonio develop what I will refer to throughout this piece as a rhetoric of intercorporeal exchange, a love language based primarily on the imagined and literal touch of the body's parts and passions.

Webster's depiction of the body and the mobility of its parts reimagines conceptions of early modern embodiment that scholars, including Gail Kern Paster, Thomas Laqueur, and Michael Schoenfeldt, have so expertly explored. ${ }^{8}$ As these critics have noted, seemingly figurative humoural descriptions of the body's interior had, for early moderns, a literal basis. In the play, the physical and psychological are very much bound together; however, Webster also depicts bodily parts as active agents that move beyond the body's frame and, in doing so, drive the narrative of the play. While characters in The Duchess of Malfi are subject to the vicissitudes of their environments and the subsequent shifts in their humoural dispositions, they are also vulnerable to the agency of both meaty organs and travelling spirits. By attending to the language of itinerant parts, through notions of sympathy developed in early modern medical and Neoplatonic texts, this essay recovers a conception of subjectivity that was inextricably linked to invasion.

We see Webster's idiosyncratic interpretation of the humoural body in the dramatic blazon. Though foundational scholarship on the lyrical blazon suggests that Petrarchan images of dismemberment erase female subjectivity and represent a body 'that is partitioned, arranged, and rearranged', the dramatic blazon complicates such readings as critics and audience members contend with the presence of the blazoned subject on stage. ' As Morrison and Deborah Uman write, 'Before death or sleep, the blazoned subject can gaze back, can draw on strategies of self-protection, can challenge the uncanny nature of dramatic dismemberment, though with varying degrees of success'. ${ }^{10}$ Webster's play stages the difficulty of containing the blazoned body as the Duchess reappropriates her brothers' language for her own means. On stage, the Duchess's blazonic rhetoric challenges more traditional examples of the lyrical blazon that render the (typically) female subject as absent or inert. Although, as Morrison and Uman claim, the blazoned 
subject in drama is oftentimes more vocal and visible - and the Duchess most certainly speaks and gazes back - the Duchess also offers an alternative to the violence of the blazon through modifying the form and imagining instead the agency of the body's parts.

In the play, the language of bodily fragmentation can create new and even desirable forms of subjectivity and physical embodiment. The couple conceives of their bodies as humourally vulnerable to one another as they imagine that the exchange of parts and fluids can shape both their physical and emotional dispositions. The Duchess first adopts (and revises) the blazonic rhetoric of her brothers as she urges Antonio to reciprocate her love. While the couple uses the blazon to convey their desire for mutual and long-lasting affection, a Neoplatonic merging of souls, if you will, in drawing attention to the agency of individuated parts, the play also underscores the materialist underpinnings of Neoplatonism. ${ }^{11}$ In the play, almost as if in response to Neoplatonism's disavowal of the body and sexual intercourse, metaphysical resemblance or 'oneness' is realized through a blazonic rhetoric of intercorporeal exchange. ${ }^{12}$

The Duchess and Antonio are both dependent on and hyper-aware of their humoural vulnerability, recognizing at times that they may be changed not exclusively by one another, but also by their environmental circumstances, including the influence of other bodies. This fear permeates the play's five acts; however, Webster emphasizes the Duchess and Antonio's unusual material intimacy by alluding to the sympathetic nature of their relationship. Although the period primarily relied on humoural medicine to understand the body's emotional and physical health, early moderns, including Neoplatonists such as Marsilio Ficino, turned to hidden antipathies and sympathies to explain 'both bonds and animosities among an unpredictable mix of plants, minerals, animals, and humans. ${ }^{13}$ Hidden sympathies (also known as occult affinities) produce shared emotional and physical states; one may feel an 'enigmatically close connection' with another person, or one may contract another's disease. ${ }^{14}$ Webster weaves together, I suggest, humoural and Neoplatonic theories, both of which are rooted in Greek thought, as well as beliefs in hidden sympathies, to dramatize a mode of intersubjective relationality that the material exchange of parts and spirits facilitates.

The couple's rhetoric, along with the play's allusions to humouralism, Neoplatonism, and hidden sympathies, reveals the deeply material foundation of the Duchess's and Antonio's affective lives. Although references to the humours often convey specific emotional states, the Duchess and Antonio's attention to the individuated part, and specifically their rhetoric of intercorporeal exchange, stresses the materially transformative nature of interpersonal relationships. The Duchess's 
hope that Antonio may feel as she does is realized through the imagined and literal exchange of flesh and fluid. While the Duchess and Antonio rely on and even revel in what Webster characterizes as their sympathetic bond - the inherent magnetism of their bodies - the Duchess, in particular, becomes anxiously aware of her humoural and sympathetic susceptibility to the world beyond their domestic sphere.

\section{Travelling Parts}

Undeterred by her brothers' warnings, the Duchess courts Antonio by turning to, and altering, the very vocabulary with which her brothers threaten her. She begins by asking Antonio for his opinion of marriage, and after receiving his rather equivocal portrayal of marriage as either a 'heaven or hell', she decides to pursue Antonio by instead focusing on his bloodshot eye:

Fie, fie, what's all this?

One of your eyes is blood-shot, use my ring to't

They say 'tis very sovereign: 'twas my wedding ring,

And I did vow never to part with it

But to my second husband.

The Duchess seizes upon this moment to initiate an exchange of bodily spirits. Although she slyly offers Antonio her wedding ring (and presumably her hand in marriage), early modern audiences would have regarded her choice of treatment as an appropriate one; according to Aristotelian beliefs in the healing properties of precious stones, jewels, especially emeralds, were thought to soothe the eye. The Duchess may be interested in offering Antonio relief; however, she might also view Antonio's bloodshot eye as a manifestation of both melancholia and love. According to Marsilio Ficino's Commentary on Plato's Symposium of Love, the 'seminal text of Renaissance love theory', feelings of love and melancholy can cause the eyes to appear red or bloodshot. ${ }^{15}$ As Marsupinni explains in the seventh speech of the Commentary, lovesickness causes vaporous spirits, produced from the blood, to '[send] out rays ... through the eyes' that can '[extend] as far as [the] person opposite.' ${ }^{16}$ In doing so, 'bleary and red eyes, by the emission of their own ray, force the ray of the beholder nearby to be afflicted with a similar disease.'. ${ }^{17}$ The release of a lover's spirits not only affects another's eyes, but also prompts a second release, causing the eyes of the beholder to release their own vaporous spirits. Melancholy, however, can prevent this exchange of bodily material. Marsupinni notes that melancholics cannot release their spirits or 'catch' 
those of the beloved on 'account of the thickness of [their] blood and spirits'18 By offering Antonio her ring, the Duchess can dilute Antonio's dense blood and enable him to capture her spirits as he releases his own.

The reciprocal release of spirits allows the Duchess to exchange bodily fluids as well as metaphysically merge her soul with Antonio's. Though the period's medical and Neoplatonic texts differ slightly in their definitions of the body's spirits, early moderns would have largely conceived of the spirits as material fluids or vapours, produced from the blood, which have the unparalleled ability to communicate directly with the body's soul. The sixth speech of the Commentary (in a portion attributed to Tommaso Benci) explains that the 'soul and the body ... are joined by means of the spirit, which is a certain very thin and clear vapor produced by the heat of the heart from the thinnest part of the blood'. ${ }^{19}$ Helkiah Crooke defines spirit as 'a subtle and thinne body always mooveable, engendered of blood and vapour, and the vehicle or carriage of the Faculties of the soule. ${ }^{20}$ Robert Burton speaks to the metaphysical properties of spirits: 'The rayes ... sent from the eyes, carry certaine spirituall vapors with them, and so infect the other party. ${ }^{21}$ Beyond enacting a one-sided marriage ceremony, by handing Antonio her ring, the Duchess facilitates the convergence of both material spirits and immaterial souls.

Though Neoplatonists privileged the spiritual over the physical, the play emphasizes that the merging of souls requires, unequivocally, the exchange of bodily stuff. While the Duchess appears here to be interested in marital and metaphysical union, her blazonic rhetoric - her attention to Antonio's bloodshot eye - alludes to the agency of bodily parts and fluids. Precisely through their mobile spirits and ocular porousness, the Duchess and Antonio may achieve some form of spiritual resemblance. As Ficino, Crooke, and Burton suggest, the body's spirits not only join the soul and material body, but also travel beyond the body's interior spaces. While Ferdinand and the Cardinal anxiously fear their sister's potentially metamorphic body — imagining her spotted liver and mobile blood - the Duchess depends upon the body's transformative potential. More precisely, she hopes that, in diluting Antonio's thickened blood, her spirits will penetrate Antonio's eyes while his too will pierce hers.

The possibility that the Duchess and Antonio may engage in an exchange of spirits aligns their bodies as mutually sympathetic to one another. The period's Neoplatonic and medical texts describe the physical effects of love - for example, the release of spirits from the eye - while simultaneously attributing love to a larger system of hidden sympathies and antipathies in which two bodies (human 
or nonhuman) could share an inexplicable and strangely close connection. Ficino, for example, writes:

Because the whole power of magic consists in love. The work of magic is the attraction of one thing by another because of a certain affinity of nature ... From this common relationship is born a common love; from love a common attraction. And this is the true magic ... Thus also the lodestone draws iron, amber draws chaff. ${ }^{22}$

While early modern medical texts address the romantic love between two people more explicitly, Ficino speaks of love as encompassing a wide range of relationships. Early moderns regarded sympathetic attractions or affinities as part of a 'preternatural realm'; however, they thought the effects of such attractions were knowable. ${ }^{23}$ Webster's play does not attempt to elucidate the basis of the couple's attraction, but instead dramatizes the material consequences of their bond.

While the brothers attempt to control the unruliness of their sister's body, the Duchess embraces such unruliness as she envisions transformations that implicate Antonio's body as well as her own. Just moments after her brothers present a disquieting image of her liver and blood, the Duchess reappropriates their language to describe a model of interpersonal relations in which the agency of flesh and fluid transforms the blazoned and blazoner. The Duchess seeks to regulate the ebb and flow of Antonio's body, specifically aiming to dilute his blood and initiate an exchange of spirits. By relying on the agency of bodily parts - in this case, spirits that leave the body to penetrate another's eyes - the Duchess moves toward a mode of relationality in which she and Antonio are composed of the very same bodily substance. She draws on blazonic language to develop what I more precisely term as a rhetoric of intercorporeal exchange. Though she, like her brothers, draws attention to the individuated part and even to the body's unpredictable qualities, what she desires is not to render the blazoned subject silent or inert. Rather, the Duchess aspires to transform with and because of Antonio, her rhetoric revealing a sense of her own physical vulnerability.

As Antonio continues to repel the Duchess's advances, the Duchess again suits the blazon to her own needs, this time imagining the flight of an organ into the body of another:

Go, go brag

You have left me heartless, mine is in your bosom,

I hope 'twill multiply love there. You do tremble. 
Make not your heart so dead a piece of flesh

To fear more than to love me.

The Duchess envisions a transplant of sorts, becoming her own anatomist as she pictures her heart lodged within Antonio's chest. She hopes that the contact of two organs will have an affective force; through these interior touches, love may multiply. Though the Duchess appears to be speaking metaphorically — presumably her heart is not, in fact, within Antonio's chest - her remark, 'you do tremble', implies the affective and physical force of this seemingly morbid blazon. That is, organs and fluids do things, but so do disturbing images of bodily parts. The Duchess's rhetoric effectively enacts what she imagines the displacement of her heart into Antonio's body might achieve. Antonio's slight, but visible shudder betrays a vulnerability to the Duchess's language. As Antonio's reaction (both here and as the scene continues) suggests, intercorporeal rhetoric — descriptions of itinerant organs - can metamorphose the body, multiplying love and making dead flesh feel.

While Webster draws attention to their sympathetic bond - Antonio seems enigmatically moved in this moment — the play also reflects on the profound physiological impact of touch. The Duchess startles Antonio with this image as she insists upon not only the mobility and agency of bodily parts, but also the transformative potential of tactility. In his Mikrokosmographia, Crooke conceives of the five senses as 'intelligencers betweene the body and the soul', without which 'there is no perception of any such vision or imagination'. ${ }^{24}$ As such, the senses influence the 'temper' or humoural composition of the body. ${ }^{25}$ Touching, for Crooke as well as other physicians, held an especially significant role: 'diffused through the whole body' and associated most with the skin, touch was considered the 'foundation of all the senses', and most readily mediated the soul's engagement with the outer world. ${ }^{26}$ Somewhat similarly, in The Passions of the Minde in Generall (1604), Thomas Wright explains that the passions and affections move between the 'immaterial ... acts of our wits and will' and the 'external and material ... acts of our senses'. ${ }^{27}$ As the senses engage with the external world, the passions and affections interpret that external world and influence the immaterial body or soul. Wright proposes, 'when these affections are stirring in our minds they alter the humor of our bodies, causing some passion or alteration in them'. ${ }^{28}$ The senses cause the mind's passions to stir and, in doing so, they induce a changed physical condition - that is, a humoural imbalance or equilibrium - as well as an altered affective state. For Wright and Crooke, the 
contact of bodies, or two organs, as we see here, could have physical and spiritual repercussions.

That Antonio then reciprocates the Duchess's affections speaks to the impact of this at once unsettling and desirable image. The Duchess, in part, deviates from Crooke's explanation of tactility as she pictures interactions that occur not upon the body's surface, but within its interior. She suggests that the interpenetration of her heart and the contact of bodily parts can create the romantic bond she desires. Though Petrarchan and courtly love poetry focuses on the heart as the site of the emotions and oftentimes imagines the possession of the beloved's heart, less common is both the displacement and contact of one organ with another. ${ }^{29}$ While what the Duchess describes is not dramatized, Antonio's visible reaction to this anatomical image conveys an understanding of interior touching as potentially desirable, dangerous, and ultimately transformative.

Antonio succumbs to the Duchess's rhetoric, eventually seizing upon the image of touching flesh. In a moment that most critics regard as the couple's wedding vows, Antonio hopes that they may 'imitate the loving palms / Best emblem of a peaceful marriage / That ne'er bore fruit divided' (1.1.473-5). As editors of the play have noted, early moderns believed that palm trees could only reproduce when planted in close proximity to one another. ${ }^{30}$ Though Antonio seems to desire what Erin Ellerbeck refers to as 'extreme grafting', the union of two trees (rather than that of a stock and scion), the double meaning of 'palm', and the likely blocking of this scene suggest that Antonio may be meditating on the generativity of not only plants, but also bodily parts. ${ }^{31}$ Following early modern nuptial rituals, the actors playing the Duchess and Antonio would have presumably clasped hands three times while reciting their vows, thus drawing the audience's attention to the repeated contact of their hands. At first glance, Antonio's wish that they bear children together rather than apart may sound like a somewhat clichéd articulation of paternal anxiety; however, rather subtly, Antonio echoes the desire for metaphysical harmony as he hopes that their touching palms, the contact of flesh with flesh, will create a 'peaceful marriage'. His focus on their palms, as well as the repeated contact of their hands during these lines, underscores the crucial role of touching parts in creating desirable affective bonds.

While Antonio does not imagine invasive organs or spirits here, he implicates his own body within this blazon as he refers to (and enacts) a mutually felt sensation. As Crooke and Wright explain, tactility leaves traces upon the body, potentially changing its emotional and physical condition. For early moderns, the hand, in particular, feels another's touch even more intensely — or as Crooke puts it, 'more curioslie and exquisitely' - than the body's other parts. ${ }^{32}$ Rhetorically and 
on stage, the Duchess and Antonio touch and feel one another while simultaneously changing with and through the other's flesh. Though this scene speaks to what scholars have identified as Webster's interest in companionate marriage and equal partnership, the play again emphasizes the material basis of such relationships. ${ }^{33}$ Within this imaginary, the independent agency of flesh, fluid, and organs serves critical roles in fulfilling the Duchess and Antonio's desire for reciprocal love and metaphysical resemblance.

\section{Staging Sympathies}

Although Webster suggests the humoural openness and sympathetic attraction of the Duchess's and Antonio's bodies - first, through the Duchess's intercorporeal rhetoric and later in Antonio's reaction to and adoption of her language - the play more fully evinces their hidden affinity as the Duchess goes into labour. That the Duchess bears children is unsurprising; ${ }^{34}$ however, Webster's decision to stage her labour demonstrates a recurrent interest in dramatizing the material effects of occult bonds. Floyd-Wilson explains that early moderns believed conception was only possible if a sympathy existed between the male seed and female womb. She cites a late sixteenth-century text, The Problemes of Aristotle, in which the author writes, 'the wombe and nature doe draw the seede, as the Lodestone doth yron.' 35 Similar to the magnetic quality associated with the lodestone, early moderns believed that if a sympathy existed between bodies, the womb could potentially attract seed, thus leading to procreation. Though Antonio's response to the image of touching hearts may be indicative of their shared bond, the play confirms the possibility of their sympathetic attraction - and its material consequences - through the Duchess's pregnancy. That is, sympathetic affinities and intercorporeal exchange do, in fact, leave bodies changed, if not irrevocably transformed. In her discussion of the 'spongy, open, receptive nature attributed to the female body', Tanya Pollard writes, 'inhabited and transformed by a new presence simultaneously native and foreign, the pregnant body represents the most extreme version of the openness and vulnerability understood to constitute women's natural state. ${ }^{36}$ Pregnancy quite literally allows the Duchess and Antonio to merge flesh with flesh. Although the play's earlier images of touching parts suggest transformations hidden within the body's interior, Webster visualizes the material effects of shared sympathies by staging the Duchess's pregnant body and eventual labour. Beyond humoural shifts, sympathetic attractions result, more radically, in the emergence of new flesh. 
The play again betrays an interest in visualizing material transformations as Antonio, too, undergoes a physical change - in the form of a nosebleed immediately after the Duchess's labour. Blood drips onto the nativity, a moment which scholars have read as a sign of the child's uncertain future. Dale B. Martin explains that 'all sorts of bleeding - through the mouth, nose, or anus - were construed by ancient medical writers as fulfilling the same corporeal function as menstruation'. ${ }^{37}$ Crooke specifies that women typically do not experience nosebleeds because their blood accumulates in the womb, either for the purpose of menstruation or fetal nourishment. ${ }^{38}$ Marking nosebleeds as a male ailment, Crooke inadvertently proposes that bleeding from the nose is comparable to the release of blood during menstruation. In his Lectures on Galen's De Sectis, Agnellus of Ravenna makes this analogy more explicitly: 'The flow of blood occurs not only through these [hemorrhoids] but also through the nose, and also by what is called menstruation or menstrual flow in women, from the fact that each month an evacuation of their bodies occurs'. ${ }^{39}$ As Crooke and Agnellus of Ravenna suggest, early moderns understood nosebleeds as a necessary and cyclical form of purgation.

Although Antonio bleeds just moments after the Duchess has suffered the release of blood and amniotic fluid, early modern playgoers would have more immediately understood Antonio's nosebleed as a bodily evacuation akin to menstruation rather than childbirth. Antonio's bleeding may imply that he is not, like his wife, giving birth, but rather experiencing a miscarriage or abortion. The Duchess's and Antonio's bodies do not perfectly align here, and perhaps Webster is gesturing toward the uncertainty of the child's fate. That said, the Duchess's staged pregnancy and labour - experiences rarely seen on the early modern stage - as well as the couple's mutual release of blood, visualizes, for audiences, the intensity of their sympathetic bond. Shared sympathies are, as Webster proposes, more than airy fluids that emanate from the eyes. They are bodies that endure pain, that bleed, and even, sometimes, give way to new flesh.

\section{Waxen Human Forms}

The Duchess's pleasure in images of permeability and fragmentation dissipates once she is separated from Antonio's side and confronted with Ferdinand's various forms of torture. Notably, Ferdinand's gift of a dead man's hand echoes the couple's clasped hands in act 1 . Ferdinand demands that they speak entirely in darkness, declaring: 
Here's a hand

To which you have vowed much love: the ring upon't

You gave.

... Bury the print of it in your heart.

As Ferdinand exits and the room is again lit with torches, the Duchess discovers that what she grips is not her brother's palm, but a dead man's hand, which she mistakes for the hand of her husband. Unlike the play's earlier insistence on mutually felt touches, the Duchess here experiences a touch that she alone feels. Katherine Rowe argues that this scene 'literalizes the gift of hands and hearts that [the Duchess] and Antonio rehearse in the wooing scene. ${ }^{40}$ She notes that 'its prosthetic, disembodied form challenges the fiction of marital couverture, or single person, that that symbolic gift is meant to sustain. ${ }^{41}$ Similarly, Albert Tricomi comments, 'Read iconographically, this purported severing of the ringed hand from the body exhibits Ferdinand's desire to revoke, untie, disassociate, his sister from a marital union he will not approve. ${ }^{42}$ As Rowe and Tricomi suggest, Ferdinand seeks symbolically to dissolve the couple's union as he forces his sister to reenact, albeit perversely, her wedding vows. Rowe and Tricomi, however, are not exactly concerned with the consequence of the dead hand's touch, that is, how its feel against the Duchess's palm may change or shape her. I would argue, however, that Webster's play, and its focus on the mutual touch of both lovers, asks the question: what are the consequences of a touch that is felt by the Duchess alone? Ferdinand, to an extent, responds to this question as he instructs the Duchess to 'bury the print of it in your heart'. Returning to the blazon, Ferdinand imagines the malleability of his sister's heart as he proposes that it serve as a grave for the print of Antonio's severed hand, disturbing the Duchess's image of touching hearts in act 1 . Rather than allowing her to envision and articulate her own metamorphoses, he again seeks to control his sister's body as he forces her to face the repercussions of a touch that she alone feels. As the Duchess and Antonio reiterate in the play's preceding acts, bodily parts do things; the exchange of parts and the touch of another's flesh, especially when felt upon the hand, alter the body's material and metaphysical condition. Though such transformations are at times desirable, even sought after, Ferdinand disrupts the couple's mutually felt sensations and, presumably, the metaphysical resemblance they have so carefully sought to achieve.

Webster further draws attention to the potential malleability of human bodies by staging waxen figures, what the Duchess believes to be the corpses of her husband and children (4.1.64 sd). During the period, wax was commonly used 
to create life-size effigies as well as portraits of eminent figures. Margaret Owens notes that although the term 'waxworks' emerged in the seventeenth century, effigies and sculpted portraits were primarily constructed out of wood; reserved for the hands and face, wax was used to create 'the rosy flesh of the living ... [or] the yellowish tones of a newly deceased body'. ${ }^{43}$ Owens surmises that the misleading term reflects wax's remarkable 'effectiveness at simulating human flesh'. ${ }^{44}$ The medium was also used to make malleable anatomical models for medical students. As Elizabeth Harvey explains, 'Wax is like flesh in its responsiveness to touch: it warms and changes shape, it seems almost to respond to touch as if it were flesh. It is, then, an ideal medium in which to fashion bodies made to be touched'. ${ }^{45}$ Visually, wax deceives the Duchess, and perhaps even audience members, because of its likeness to human flesh; only once the Duchess has exited the scene does Ferdinand admit to Bosola, 'These presentations are but framed in wax' (4.1.109). Her inability to distinguish wax from flesh not only affirms the visual similarity between the two forms, but also raises the possibility that the dead man's hand was fashioned out of wax. ${ }^{46}$

In its engagement with waxworks, the play emphasizes the ongoing metamorphic quality of human bodies, their ability to transform and bear, even if only subtly, the shape of their environments. Given the pliability of wax, the heat of the Duchess's palm or the chill of her fingertips could alter the waxen hand's shape and temperature. The Duchess, too, in feeling the waxen form, may experience a feeling of warmth or coldness as her palm and fingertips adjust to the hand's shape. Both hands - wax and flesh — are touched and potentially changed by the encounter. While an element of reciprocity exists in this exchange, suggestive of the couple's clasped palms, the hand lacks sentience, and thus only the Duchess can experience the sensation of temperature and form. Though the Duchess believes she has grasped Antonio's hand and gazed upon his body and those of their children, she recognizes in these moments her own waxiness, her potential to change and thus alter the metaphysical resemblance she has established with Antonio. She tells Bosola that the sight of her deceased husband and children

wastes me more

Than were't my picture, fashioned out of wax,

Stuck with a magical needle, and then buried

In some foul dung-hill.

Although the Duchess seems convinced that these corpses are, as Ferdinand puts it, 'true substantial bodies', she references wax magic to convey the effect of this ghastly scene. As Lynn Maxwell explains, the practice of wax or sympathetic 
magic involved creating an object 'to impact a subject across a distance on the basis of shared qualities or characteristics. 47 Struck with a needle and buried in a dunghill, the Duchess's portrait could physically harm her body, but according to the Duchess, not quite as much as the sight of her deceased family. The Duchess betrays here not only the intensity of her grief, but her concern with the extent to which this display and knowledge 'waste' or affect her.

Rather than countering her brother's abuse with her own form of blazonic rhetoric, the Duchess imagines her death through various ontological transformations that lean toward the stony, the still, and the cold. She seems acutely aware that her environmental circumstances, and specifically her brother's violence, may act upon her body and mind. After feeling the dead man's hand and confronting the waxen bodies, the Duchess considers three forms of suicide: she first wishes, 'If they would bind me to that lifeless trunk / And let me freeze to death' (4.1.66-7). She then exclaims, 'Portia, I'll new kindle thy coals again / And revive the rare and almost dead example / Of a loving wife' (70-2). Although Bosola reminds her that she is 'a Christian', the Duchess conceives of a third way to die, remarking, 'The Church enjoins fasting: / I'll starve myself' (73-4). The Duchess rejects Portia's example, not out of concern for her faith — she, after all, proposes another way by which to end her life - but because the swallowing of hot coals requires a more immediate and severe bodily alteration than freezing and fasting.

The Duchess may regard hypothermia and starvation as ways of disengaging with the external world and, perhaps at least to a certain degree, preserving the current condition of her body as shaped by Antonio. Although freezing involves a change in the body's core temperature (and, for early moderns, the body's humoural state), the double meaning of the word suggests that the Duchess desires to capture permanently the current state of her body, almost as if freezing a moment in time. Specifying that she wishes to die against Antonio's trunk or torso, she evokes the intercorporeal rhetoric of the play's first act. ${ }^{48}$ Just as she imagines her heart within Antonio's bosom, here she similarly pictures the contact of their chests as they engage in a mutual touch. Frozen against Antonio's chest, the Duchess may also protect herself from the influence of other touches and bodies. Similarly, starvation may strike the Duchess as an attractive possibility because the rejection of foodstuffs and drink would exclude her from larger communal and agricultural ecologies. Though again, as with hypothermia, the gradual process of starvation would undoubtedly transform her body, the Duchess seems intent on preserving the material resemblance she has achieved with Antonio. 
The Duchess further expresses concern over the physical condition of her body as she asks her serving woman, Cariola, 'Who do I look like now?' (4.2.30). As Morrison writes, 'her question ... suggests an ongoing metamorphic quality such that one's exterior changes, tracking in response to interior shifts. ${ }^{49}$ Cariola's response - 'Like to your picture in the gallery, / A deal of life in show but none in practice; / Or rather like some reverend monument' (31-3) — figures the Duchess as an art object, a portrait or statue of her former self. Although the Duchess rejects the image of the 'alabaster' widow in act 1 (1.1.446), she appears pleased by Cariola's assessment, declaring it 'Very proper' (4.2.34). She clings to these depictions of herself as a painting or monument because they imply the impenetrability of her body and serve as proof of her resistance to her brother's violence. These images of the Duchess as artwork, moreover, starkly contrast the allusions to bodily permeability and travelling parts that the Duchess relies upon in act 1 . Though she renders her body (and Antonio's) as materially penetrable when by Antonio's side, separated from him, the Duchess seeks solace in conceptualizing her body as stony and fixed as a work of art.

Though scholars have debated the extent to which Ferdinand's tortures affect the Duchess, her final moment on stage underscores her immunity to the touch of other bodies. Immediately following her strangulation, the Duchess stirs, and Bosola, regretting the murder, declares: 'She's warm, she breathes: / Upon thy pale lips I will melt my heart / To store them with fresh colour' (4.2.333-5). He then proceeds to kiss her, hoping that this gesture may restore colour to her lips and life to her frame. Bosola appears to understand - perhaps from observing the lovers - that body parts do things. His blazonic vocabulary is as uncanny as the Duchess's in act 1; he imagines that his heart, moving beyond his chest, will enliven the Duchess as it melts upon her lips. Picturing his melted heart, Bosola alludes to the potential malleability and agency of his own body. Just as waxen forms may melt upon touching human flesh, Bosola suggests that his heart, too, may transform as it makes contact with the Duchess's lips. We, of course, do not see Bosola's heart depart from his body, nor do we see the intended curative effects of this kiss. The Duchess briefly cries for Antonio, and after learning he is still alive, she utters 'mercy' and dies (339-43). Although Antonio is not on stage during this scene, Webster draws attention to the sympathetic nature of the lover's relationship by dramatizing the inefficacy of Bosola's rhetoric and touch.

As I show, Webster offers an alternative to the more violent depictions of women's bodies as his tragic heroine uses the language of dismemberment and disfiguration for her own ends. What I refer to as the Duchess's rhetoric of intercorporeal exchange allows spirits to pass between the lovers' eyes; it causes Antonio 
to tremble and reciprocate her love; and perhaps most importantly, it reveals a conception of emotional embodiment predicated on the body's susceptibility to invasive spirits and parts. The couple's desire for metaphysical resemblance depends upon the sympathetic attraction of their bodies and their humoural openness to the very material and reciprocal transformations they describe. Perhaps shared by audiences too, the Duchess's worry that she may be changed once separated from her beloved, in death, ironically subsides.

\section{Notes}

I would like to thank the anonymous readers at Early Theatre for their thoughtful reports. Thank you, too, to Perry Guevara, Alicia Andrzejewski, and Danica Savonick for so generously commenting on multiple drafts. I am especially grateful for Tanya Pollard's encouragement and thorough feedback on earlier versions of this piece.

1 John Webster, The Duchess of Malfi, ed. Brian Gibbons (New Mermaids, 2001). Text references are to act, scene, and line of this edition.

2 Helkiah Crooke, Mikrokosmographia: A Description of the Body of Man (London, 1615), 7. By additionally referencing this tale - and comparing the livers of the luxurious to Laban's spotted sheep - Ferdinand implies that remarriage is akin to bestial and even interspecies intercourse and results in progeny who are visibly marked by their illicit conception. According to Genesis 30, Laban and Jacob divided Laban's flock, so that Jacob would have ownership of all the spotted, stripped, or black animals. Jacob, however, still tended Laban's flock, and in order to increase his own herd, he placed spotted lumber in front of Laban's animals while they mated. By gazing on the spotted wood, the sheep would produce speckled offspring. Jacob's method of breeding allowed him to trick Laban and acquire more sheep. Thus, Ferdinand's reference to the tale aligns the liver's spots and, more precisely, feminine desire with clandestine and bestial intercourse.

3 The Duchess responds to the brothers' negative valorization of material exchange their perceived threat of degraded fluids and tainted parts - by imagining an alternative in which social relations do not diminish, but instead increase one's inherent worth. She proposes that 'Diamonds are of most value / They say, that have passed through most jewelers' hands' (1.1. 292-3). As the Duchess equates herself to a 'diamond', a stone of considerable value and an early modern symbol of chastity, she emphasizes that contact with different hands increases the diamond's value. 
4 Theodora Jankowski, 'Defining/Confining the Duchess: Negotiating the Female Body in John Webster's The Duchess of Malfi', Studies in Philology 87.2 (1990): 229.

5 Linda Woodbridge, 'Queen of Apricots: The Duchess of Malfi, Hero of Desire', The Female Tragic Hero in English Renaissance Drama, ed. Naomi Conn Liebler (New York, 2002), 172, https://doi.org/10.1007/978-1-137-04957-5.

6 Sara Morrison, 'Embodying the Blazon: Performing and Transforming Pain in Measure for Measure and The Duchess of Malfi', Staging the Blazon in Early Modern English Theater, ed. Deborah Uman and Sara Morrison (Surrey, 2013), 78, https:// doi.org/10.4324/9781315610535.

7 Scholars working in the field of affect studies have defined affect/affective in a multitude of ways, some using the term to discuss non-articulated feelings, while others use it synonymously with emotion. In this essay, I use the term affect/affective to denote embodied emotions, acknowledging that, for early moderns, feelings had a material basis and were subject to the body's social and environmental conditions.

8 See Gail Kern Paster, Humoring the Body: Emotions and the Shakespearean Stage (Chicago, 2004), https://doi.org/10.7208/chicago/9780226648484.001.0001; Thomas Lacqueur, Making Sex: Body and Gender from the Greeks to Freud (Cambridge, 1990); Michael Schoenfeldt, Bodies and Selves in Early Modern England: Physiology and Inwardness in Spenser, Shakespeare, Herbert, and Milton (Cambridge, 1999).

9 Nancy Vickers, 'Members Only: Marot's Anatomical Blazon', The Body in Parts: Fantasies of Corporeality in Early Modern Europe, ed. David Hillman and Carla Mazzio (New York, 1997), 19.

10 Morrison and Uman, 'Setting the Stage', Staging the Blazon in Early Modern English Theater, 6, https://doi.org/10.4324/9781315610535-1.

11 Lesel Dawson, Lovesickness and Gender in Early Modern English Literature (Oxford, 2008), 165, https://doi.org/10.1093/acprof:oso/9780199266128.003.0005. Neoplatonists sought to combine elements of Christianity with Platonic ideals regarding romantic love. According to such formulations, the beloved functions as a means by which the lover can gain spiritual transcendence as they move 'from loving the body to loving the soul, and finally loving God' (134).

12 Although Neoplatonists attempted to revise Platonic theory's celebration of malemale love by instead focusing on the spiritual possibilities of heterosexual relationships, writers such as Marsilio Ficino and Giordano Bruno still privileged non-sexual male friendships while warning readers of the dangers of physical desire.

13 Mary Floyd-Wilson, Occult Knowledge, Science, and Gender on the Shakespearean Stage (Cambridge, 2013), 1, https://doi.org/10.1017/CBO9781139567541.

14 Ibid, 7. 
15 Michael J.B. Allen, introduction to Marsilio Ficino: His Theology, His Philosophy, His Legacy, ed. Michael J.B. Allen and Valery Rees (Leiden, 2001), xiii. Jill Kraye, 'Ficino in the Firing Line: A Renaissance Neoplatonist and His Critics', Marsilio Ficino: His Theology, His Philosophy, His Legacy, 382, notes that other authors, such as Pietro Bembo, Baldassare Castiglione, and Giordano Bruno, 'modified [Ficino's] theory to suit the taste of their readers, transforming, for instance, the homoerotic desire celebrated by Plato and Ficino into the more acceptable heterosexual passion familiar from courtly love and Petrarchan poetry'. While we do not know whether Webster read Ficino's Commentary, by the seventeenth century, these ideas would have certainly been familiar to English writers and audience members. Sarah Hutton, 'The Renaissance and the Seventeenth Century', Platonism and the English Imagination, ed. Anna Baldwin and Sarah Hutton (Cambridge, 1994), 72, notes that English readers were likely most familiar with the Latin translation of Castiglione's The Courtier. She writes that 'the doctrine of Platonic love was assimilated into secular love poetry, especially into the Petrarchan poetry so fashionable in the fifteenth and sixteenth centuries'.

16 Marsilio Ficino, Commentary on Plato's Symposium on Love, trans. Sears Jayne (Dallas, 1985), 159, 160.

17 Finico, Commentary, 160.

18 Ficino, Commentary, 166. Dawson, 'Lovesickness and Neoplatonism', 129-30, points out that lovesickness was commonly associated with melancholy and illness in texts such as Robert Burton's The Anatomy of Melancholy and even in Ficino's Commentary.

19 Ficino, Commentary, 115.

20 Crooke, Mikrokosmographia, 174.

21 Robert Burton, The Anatomy of Melancholy (London: 1615), 561.

22 Ficino, 127. Mary Floyd-Wilson's Occult Knowledge first drew my attention to this passage.

23 Floyd-Wilson, Occult Knowledge, 1.

24 Crooke, Mikrokosmographia, 6.

25 Ibid, 5. Unlike the other senses, touch does not always affect the body's composition. As Crooke explains, 'if therefore the Object bee of the same temper with the Instrument, the sense [touch] is not affected therewith, because it doth not suffer by that which is like unto it' (531). The Duchess, however, imagines that Antonio is, in fact, moved physically and perhaps even emotionally by the contact of their hearts.

26 Ibid, 531, 6.

27 Thomas Wright, The Passions of the Minde in Generall (London, 1604), 7.

28 Ibid. 
29 William W.E. Slights, The Heart in the Age of Shakespeare (Cambridge, 2008), explains that the period inherited much of its beliefs about the organ from classical texts (104). Plato identifies the heart as the body's 'guard', which upon perceiving an exterior threat produces 'heat' and the 'whole power of feeling in the body' (150), while Aristotle argues that the organ is 'the origin of life and of all movement and perception' (54). Slights explains that Galen, following Plato, believes 'spiritual and emotive vitality' is located in the heart (104). Slights proposes that, in spite of the period's medical advances, anatomists such as Vesalius, Fabricius, and even Harvey held confidence in these earlier traditions which 'harmonized heart and soul' (104).

30 John Webster, The Duchess of Malfi, ed. René Weis (Oxford, 2009), 391.

31 Erin Ellerbeck, "A Bett'ring of Nature": Grafting and Embryonic Development in The Duchess of Malfi', The Indistinct Human in Renaissance Literature, ed. Jean Feerick and Vin Nardizzi (New York, 2012), 93, https://doi.org/10.1057/9781137015693.0013. Ellerbeck explains that, during the period, writers often used the metaphor of grafting to 'signal a disruption of the social order', particularly in reference to 'prohibited reproduction' (88).

32 Crooke, Mikrokosmographia, 730.

33 For scholarship on companionate marriage and equal partnership in the play, see, for example, Jankowski, 'Defining/Confining the Duchess'; Margaret Mikesell, 'Matrimony and Change in Webster's Duchess of Malfi', Journal of the Rocky Mountain Medieval and Renaissance Association 2 (1981), 97-111; Sid Ray, Holy Estates (Cranbury, 2004); Mary Beth Rose, 'The Heroics of Marriage in Othello and The Duchess of Malfi', Shakespearean Tragedy and Gender, ed. Shirley Nelson Garner and Madelon Sprengnether (Bloomington, 1996).

34 I mention this outcome's unsurprising nature while acknowledging the unusual gap in time between acts 2 and 3 as well as the infrequency of pregnant characters on the early modern stage.

35 Floyd-Wilson, Occult Knowledge, 76.

36 Tanya Pollard, 'Conceiving Tragedy', Shakespearean Sensations: Experiencing Literature in Early Modern England, ed. Tanya Pollard and Katherine Craik (Cambridge, 2013), 89.

37 Dale B. Martin, 'Contradictions of Masculinity: Ascetic Inseminators and Menstruating Men in Greco-Roman Culture', Generation and Degeneration: Tropes of Reproduction in Literature and History from Antiquity to Early Modern Europe, ed. Valeria Finucci and Kevin Brownlee (Durham, 2001), 102, https://doi. org/10.1215/9780822380276-004.

38 Crooke, Mikrokosmographia, 195. 
39 Cited in Gianna Pomata, 'Menstruating Men: Similarity and Difference of the Sexes in Early Modern Medicine', Generation and Degeneration: Tropes of Reproduction in Literature and History from Antiquity to Early Modern Europe, ed. Valeria Finucci and Kevin Brownlee (Durham, 2001), 124, https://doi.org/10.1215/9780822380276$\underline{005}$.

40 Katherine Rowe, Dead Hands: Fictions of Agency, Renaissance to Modern (Stanford, 1999), 94.

41 Ibid.

42 Albert Tricomi, 'The Severed Hand in Webster's Duchess of Malfi', SEL Studies in English Literature 1500-1900 44.2 (2004): 355, https://doi.org/10.1353/sel.2004.0023.

43 Margaret Owens, 'John Webster, Tussaud Laureate: The Waxworks in The Duchess of Malfi, English Literary History 79.4 (2012): 863, https://doi.org/10.1353/ elh.2012.0032.

44 Ibid.

45 Elizabeth Harvey, Sensible Flesh: On Touch in Early Modern Culture (Philadelphia, 2003), 101-2.

46 Following convention, if tasked with creating a waxen hand, the play's sculptor would have used wax alone to form the hand while creating a composite structure to represent the deceased bodies.

47 Lynn Maxwell, 'Wax Magic and The Duchess of Malfi', Journal for Early Modern Cultural Studies 14.3 (2014): 32, https://doi.org/10.1353/jem.2014.0033.

48 The Oxford English Dictionary's (OED) arboreal and corporeal definitions of 'trunk' emphasize the segment of a tree or human body that is distinct from the branches and limbs: 'the main stem of a tree, as distinct from the roots and branches; the bole or stock' and 'the human body, or that of an animal, without the head, or especially without the head and limbs'. OED Online, s.v. 'trunk'.

49 Morrison, 'Embodying the Blazon', 78. Morrison proposes that the Duchess seeks to 'establish a stable sense of herself' by rejecting the metamorphic quality so often attributed to women's bodies. I argue that the Duchess instead embraces the potential transformation of both her body and Antonio's as she adopts her brothers' blazonic rhetoric to suit her own ends. She seeks bodily and mental stability once she can no longer be changed through and with her beloved. 